\title{
MISCELLANEOUS.
}

\section{On the Gingee Squirrel of Sonnerat.}

Sonnerat, in his 'Voyage' (vol. ii. p. 140), very shortly describes a Squirrel, under the name of $l$ Ecureuil de Gingi, thus :-

"Rather larger than Sciurus vulgaris; fur entirely earthy grey, paler on the belly, legs, and feet; on each side of the belly is a white streak extending from the armpits to the thighs; eyes surrounded with white ; tail entirely black, with some white hairs." The following names have been given to the subject of this notice :-

Sciurus dschinschicus, Gmelin, S. N. i.p. 151.

S. gingianus, Shaw, Zool. ii. p. 147; Kuhl, Beitr. 67.

S. albovittatus, Desm. Mam. 358; Horsf. Zool. Java.

S. albovittatus, var. dschinschicus, Fischer, Syn.

Macroxus albovittatus, Lesson.

Gingee is in the Carnatic, near Pondicherry. Sonnerat's description has been considered to indicate a variety of Xerus setosus of Africa, which has spiny fur; but in that animal the streak is on each side of the back, and not on the sides of the belly. There is not a word in the short description to lead one to believe it was a spiny Squirrel, or lived on the ground; and I have never seen a Xerus from India. Sonnerat's animal either belongs to a species not in European museums and not noticed by recent Indian naturalists, probably allied to S. platani of Java, or it may be a variety of the Macroxus bicolor, which is found in various parts of India and the Malay peninsula. It would be very interesting to receive a specimen, agreeing with Sonnerat's description, from the Carnatic.-J.E. Gray.

On the Mode in which certain Rotatoria introduce Food into their Mouths. By E. Claparède.

In the Zygotrocha of Ehrenberg the vibratile apparatus may be regarded as double. The movement of the cilia is always in the same direction and opposite to that of the hands of a watch; hence it is directed towards the mouth in the right wheel and from it in the left one. But observation proves that food passes to the mouth both from right and left, which is incompatible with the received notion that the currents conveying the food are produced by the vibratile apparatus. The examination of such Rotatoria as the Melicertce and Lacinularice leads to the same result.

In Melicerta ringens, on the lower surface of the membranous vibratile organ and parallel to its margin, M. Claparède finds a sort of crest, between which and the margin there is a deep furrow. The extreme margin bears the well-known large cilia: the crest also 


\section{$2 \mathrm{BHL}$ Biodiversity Heritage Library}

1868. "On the Gingee Squirrel of Sonnerat." The Annals and magazine of natural history; zoology, botany, and geology 1, 309-309.

https://doi.org/10.1080/00222936808695698.

View This Item Online: https://www.biodiversitylibrary.org/item/88449

DOI: https://doi.org/10.1080/00222936808695698

Permalink: https://www.biodiversitylibrary.org/partpdf/65472

\section{Holding Institution}

Smithsonian Libraries

\section{Sponsored by}

Smithsonian

\section{Copyright \& Reuse}

Copyright Status: Public domain. The BHL considers that this work is no longer under copyright protection.

This document was created from content at the Biodiversity Heritage Library, the world's largest open access digital library for biodiversity literature and archives. Visit BHL at https://www.biodiversitylibrary.org. 